American Journal of Qualitative Research

June 2019, Vol.3 No. 1, pp. 1-19

https://doi.org/10.29333/ajqr/5808

(C) 2019 AJQR. http://www.ajqr.org

AMERICAN

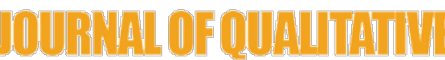

RESEARCH

ISSN: 2576-2141

\title{
"The Reward was Worth the Sacrifice": How Membership in Black Greek Letter Fraternities (BGLFs) Redefines Black Men's College Experiences
}

\author{
Jasmine Armstrong ${ }^{1}$ \\ Florida State University
}

\begin{abstract}
This study examines how membership in black Greek letter fraternities (BGLFs) significantly impacts black men's college experiences at a predominantly white institution (PWI) of higher learning. Utilizing twenty semi-structured, open-ended interviews with black male college students, this paper describes the benefits and costs of belonging to black fraternities. Membership in black fraternities fosters members' sense of personal growth and maturity, playing a pivotal role in their transformation from adolescents into young college men. On the other hand, belonging to such fraternities often consumes the majority of respondents' personal time and leads to a loss of individualism and decreased quality in personal relationships, particularly in relationships with women. This study expands upon the emerging literature on the influence that black fraternities have on their members ' college experiences by capturing fraternity brothers' own nuanced accounts of the rewards and sacrifices that are associated with membership in BGLFs. Taken together, their stories serve to counteract a host of negative stereotypes about young black men in America.
\end{abstract}

KEYWORDS: Race, Gender, Black Men, Greek Letter Organizations, Black Masculinity, College Students

\section{Introduction}

Despite an increase in black men's college attendance in recent years in the United States, the number of black men attending predominantly white institutions (PWI) of higher learning has actually declined (Ginder, Kelly-Reid \& Mann, 2014; Lopez \& Gonzalez-Barrera, 2014; Saenz et al., 2007). On average, the black student population is relatively small at less than 20 percent of the student population on white-dominated campuses (Ginder et al., 2014; Harper, 2012). It is important for students of color, particularly for black students, to have successful social and

\footnotetext{
${ }^{1}$ Dr. Armstrong received her PhD from Department of Sociology at the Florida State University. E-mail: $\underline{\text { Ja13g@my.fsu.edu }}$
} 
academic integration into the campus life of predominantly white institutions for their social engagement, student leadership, and psychological well-being ("Advancing success," 2014; Guiffrida, 2003; Kimbrough \& Hutcheson, 1998; Patton, Bridges, \& Flowers, 2011; Schmidt, Piontkowski, Raque-Bogdan, \& Ziemer, 2014). African American student organizations, including Greek organizations, serve as agents for social integration of students of color (Guiffrida, 2003). Although researchers have examined how African American student organizations help black students become socially and academically integrated at PWIs, relatively little is known about the specific role that black Greek letter fraternities (BGLFs) play in this process (Guiffrida, 2003; Hayek, Carini, O'Day, \& Kuh, 2002; Patton et al., 2011; Pike, 2003).

Research on BGLFs has emphasized the educational and social benefits of joining these fraternities, such as a sense of racial solidarity among black students, higher academic achievement for their members compared to non-Greek students, and an increase in campus and community engagement (Harper, 2007; Nelson, Halperin, Wasserman, Smith, \& Graham, 2006; Kimbrough \& Hutcheson, 1998; Smith \& Mignon, 2000; Strayhorn, 2010). Black fraternity men exhibit professionalism, sophistication, self-discipline, and productivity, providing a stark contrast to pervasive stereotypes of black men as shiftless and uneducated (Allen, 1992; Harper, 2007; Kimbrough \& Hutcheson, 1998; McClure, 2006; Ray \& Rosow, 2012). Black fraternities promise to improve the quality of African American men's college years through a combination of brotherhood, mentorship, and networking (McDonalds et al., 2007; Roberts, 1994). Nevertheless, the experience of joining and belonging to these fraternities merits closer examination.

A growing body of literature has called for an analysis of different types of institutions and how student involvement may impact college experiences for students of color (Allen, 1992; Desousa \& Kuh, 1996; Guiffrida, 2003; Harper, 2007; Kimbrough \& Hutcheson, 1998; Patton et al., 2011; Lafer \& Tarman, 2019). Results from black men's campus engagement may inform administrators in higher education on institutional effectiveness and black men's individual personal development and achievement, presently and in their future. This empirical investigation is systematically important since it seeks to shed light on how college campuses reproduce or reduce social inequality, particularly by maintaining or undermining men's social and academic success in college. This study analyzes men's experiences of Greek affiliation, outcomes from membership, and men's reactions to the outcomes.

This study contributes to existing scholarship by drawing upon black fraternity brothers' voices in order to specify the range of positive and negative consequences of belonging to BGLFs. As I will demonstrate, young black men often characterize their membership in black fraternities as being fraught with unexpected challenges. Belonging to such fraternities often consumes the majority of their personal time and leads to a loss of individualism and decreased quality in personal relationships, particularly in relationships with women. Ultimately, however, membership in black fraternities fosters these young men's sense of personal growth and maturity, playing a pivotal role in their transformation from adolescents into young college men. The young men's stories herein bring us a step closer to understanding how black fraternities can best serve as agents of academic and social integration, as channels for student retention and, finally, as gateways to lifelong success. 


\section{Literature Review \\ Black Greek Letter Fraternities (BGLFs)}

After being denied entry into white Greek letter fraternities and witnessing the blatant racism and discrimination at predominantly white institutions, black men created their own college fraternities (Hughey, 2008; Hughey \& Parks, 2011). On December 4, 1906, the first BGLF was formed at Cornell University. Soon thereafter, black fraternities were established at other PWIs. Its mission was to develop leaders, promote academic excellence, and provide service to the community. Black fraternities at other PWIs strived for the racial advancement and continued success of their members. The intended purpose of BGLFs was to address the social, political, and economic struggles of African Americans on college campuses so that African American students could have a platform to express their own college experiences (Hughey \& Parks, 2011; Kimbrough \& Hutcheson, 1998; McClure, 2006). Black men in BGLFs aspired to make an impact on their college campuses through their strong campus leadership, involvement within their communities, and focus on scholastic achievement.

\section{Visibility and Accountability Mechanisms Policing BGLF Members}

On predominantly white campuses today, amid a sea of white faces, young black men wearing their Greek letters stand out and are highly visible not only to their fellow black fraternity members, but to the student population as a whole (Ray \& Rosow, 2012). Observing BGLFs on a predominantly white campus, Ray and Rosow (2012) noted that white fraternity men experienced lower levels of visibility and accountability, while black fraternity men managed higher levels of visibility and accountability within the black and white student populations. The heightened visibility of black Greeks introduces higher levels of accountability not only from fellow Greek members, but also from mentors, the student community, faculty, and university administrators.

Black fraternity men often sacrifice their individual identity in favor of their fraternal group identity and succumb to pressures to represent their fraternity well on campus (Rawls, 2000). For instance, black fraternity men tend to collectively wear their Greek letters around campus in order to promote their fraternity to their peers and faculty and, implicitly, to oppose the stereotype of black men only attending college as student athletes.

\section{Black Greek Letter Fraternities' Treatment of Women}

There is relatively little literature comparing white and black fraternities' treatment of women. Still, researchers have found that black fraternity men are more conscious in their treatment of women because of their greater accountability to the student community (Hughey \& Parks, 2011; McClure, 2006; Ray \& Rosow, 2010; Ray, 2012;). Due to the accountability of the student body and BGLFs' visibility on campus, black men's peers can negatively perceive black men's interactions with women as hookups. Therefore, black men approach women respectfully with romantic intentions in order to present themselves well and protect their fraternity's reputation (Ray, 2012). White fraternity men objectify women by hosting fraternity parties at their houses, approaching women using sexual language, and replacing romantic relationships with college hook-ups. Consequently, BGLF men's treatment of women is different from white fraternity men's treatment of women (Ray \& Rosow, 2010).

\section{Student Involvement and Academic Engagement of Black Fraternity Men}

The literature has shown that membership in Greek organizations increases students' involvement on campus through leadership positions and participation in multiple student organizations (Hayek et al., 2002; Kimbrough \& Hutcheson, 1998; McClure, 2006; Patton et al., 2011; Wilder \& McKeegan, 1999). This is particularly true for black students on predominantly white campuses. Black Greek letter organization (BGLO) members are more involved in campus 
activities and organizations than non-Greek black students, holding more than one or two leadership positions (Kimbrough \& Hutcheson, 1998). Moreover, black students in BGLOs experience a higher level of confidence in their abilities to perform leadership skills, because their involvement in BGLOs provides them greater opportunities to practice their skills (Kimbrough \& Hutcheson, 1998).

Some scholars have found that involvement in Greek letter fraternities does little to stimulate the academic success of black males by limiting the time available to study for classes or complete coursework, or otherwise making it difficult for students to balance schoolwork with fraternity life (Hevel et al., 2015; Nelson et al., 2006; Pike \& Askew, 1990). For instance, Suzy Nelson and her colleagues (2006) found that the collegiate grade point average (GPA) of members in Greek organizations drastically declined when they joined their respective Greek organizations. Specifically, they found a significant decline in students' GPAs in the semester or two immediately after they became members of Greek fraternities or sororities. Not surprisingly, this decline was attributed to the adjustment to Greek life, and not devoting an adequate amount of time to coursework (Nelson et al., 2006).

\section{African American Male College Students Resist Prevalent Black Stereotypes}

Black college men experience discrimination and hostility at predominantly white institutions (PWIs), which adversely impacts their achievement, integration, and retention (Bohr et al., 1995; Fries-Britt \& Griffin, 2007; Harper, 2008; Steward, Jackson, \& Jackson, 1990). The men become motivated to challenge stereotypes and negative assumptions through their academic engagement and student involvement in campus organizations. Stereotypes strongly influence how people interact, communicate, and establish relationships with others around them. In the media, black men are often portrayed as criminals, gang members, thugs, athletes, and entertainers. Within these stereotypical depictions, black men are viewed as hostile, angry, sexually aggressive, and sometimes violent. Black men are rarely characterized as academically gifted or depicted as "nerds" (Fries-Britt \& Griffin, 2007; Harper, 2008; Hunter \& Davis, 1992; Steward et al., 1990).

Black men resist prevalent stereotypes regarding their academic abilities by approximating the notion of the "ideal black student" through their campus leadership and student involvement (Blake \& Darling, 1994; Fries-Britt \& Griffin, 2007; Oliver, 1989). The "ideal black student" describes a black student who is high achieving in their academics, is well known throughout campus from their leadership and student involvement within the campus and community, and who is socially engaged and considered friendly and personable by the student body. Lastly, an "ideal black student" is a great social networker, having the ability to interact with people of different racial/ethnic groups successfully (Fries-Britt \& Griffin, 2007). Black men's academic achievement and engagement in campus activities, as well as their highly visible leadership positions, enable them to challenge and dispel pervasive stereotypes about black men (Harper, 2012).

\section{Methods \\ Research Design}

Past research reveals that black men join black Greek-letter fraternities to establish strong relationships with other black men in college. More work from a qualitative approach is needed in order to understand other reasons black men become members of Greek fraternities and adjust to life after "going Greek." However, there is a paucity of research that directly examines black men's experiences of Greek life and its impact on their college development. My research could matter to university administrators committed to creating policies and practices that enhance students' 
experiences, especially considering the heightened visibility of black men on majority white campuses, which can hurt these student's pursuit of a rewarding college experience.

Research Questions. I used in-depth interviews to answer the following research questions: (1) What are some of the positive and negative consequences of membership in BGLFs? (2) What expectations are black fraternity men expected to uphold? (3) How has their involvement in black fraternities affected respondents' personal relationships (e.g., family, friendships, and romantic relationships)? In the interviews, participants described their college experiences, their interactions with women, misperceptions of their fraternity by their peers, and how they became interested in joining their Greek fraternity.

Case Selection and Sample. Data from this study comes from in-depth interviews with 20 black fraternity members at a large public research university in the southeastern United States. Nine respondents were members of Beta Sigma Rho Fraternity Incorporated ( $\beta \Sigma \mathrm{P})$, six respondents were members of Theta Psi Pi Fraternity Incorporated $(\theta \Psi \Pi)$, and five respondents were members of $\mathrm{Mu}$ Gamma Xi Fraternity Incorporated (МГE). From the approval of the University's National Panhellenic Council, I contacted the presidents of the black Greek letter fraternities on campus. The National Panhellenic Council (NPHC) is responsible for acting as the governing body for the nine historically black Greek organizations. Using the presidents as gatekeepers, I recruited participants at monthly chapter meetings and scheduled interviews with members at these meetings. I employed a snowball sampling technique, asking participants to refer other black fraternity men to interview for the study.

To address my research questions relating to how members decided to join their fraternities vary by social characteristics of black men, I targeted a diverse sample in terms of age and student involvement. Men at the university came from various household compositions, with fourteen reporting from a two-parent household, nine reporting from a nuclear household, five men reporting from a blended household, and four reporting from a single-parent household. Respondents were asked about their age with nineteen respondents identified between the ages of 20-23 years old, with the exception of one respondent who started college at age 29 . In regard to race, all of my respondents self-identified as black. Information on age, household composition, and membership in black Greek letter fraternities was obtained by asking demographic information. Table 1 reports details on the sample.

Interviews ranged from 30 minutes to 120 minutes, with a mean interview length of 54 minutes. Most interviews were completed in one sitting and conducted on the college campus. Each interview was tape recorded which allowed me to focus on the participant's responses. Pseudonyms were given to ensure the confidentiality of participants involved in the study, including the official names of the fraternities mentioned throughout the interviews. I paid close attention to how men described their college experiences and asked for specific examples of them encountering positive and negative outcomes from BGLF membership.

Most interviews began with questions regarding the men's childhood experiences and their transition to college. I asked them if they were familiar with black Greek letter fraternities in the past and how their perceptions of Greek life changed during their first year in college. As the interview progressed, I turned to the interview guide, and allowed participants' answers to shape the direction of each interview, as recommended by several qualitative researchers (Denzin \& Lincoln, 1994; Weiss, 1994). For example, several men mentioned not trusting their peers and women when asked how their Greek affiliation affected their personal relationships, and so I pursued the direction rather than redirecting them so that we could strictly follow the interview protocols. This process led to rich data. I found that men from Theta Psi Pi fraternity encountered 
greater experiences of visibility and peer recognition due to peers considering them to be popular on campus. I found that men who had increased personal growth from being in their fraternity tended to be men involved on the executive board of their fraternities.

I noticed a pattern that appeared during the interview process. When I asked participants about whether they were able to maintain relationships outside of their fraternity involvement, many said "no." Yet, surprisingly, when I asked them why the fraternity may affect their personal relationships, they said they had little free time to devote to establishing personal relationships. It became a pattern of men initially stating their fraternity membership greatly benefited their college experience, yet they modified their responses after being asked about adverse experiences being a fraternity man. Some said they had not realized how it affected their experiences until they were asked directly what aspects of Greek life were detrimental to their college experience.

\section{Data Analysis}

Coding Procedure. Once the data was collected, interviews were transcribed verbatim using Microsoft Word. My coding schemes transformed pre-set codes of the two themes (personal growth in BGLFs and unexpected costs of BGLF membership) into a list of several additional codes. The list of codes featured pre-set codes and descriptive codes such as "trust issues with women" and "group identity." The list of codes generated categories or pattern codes that helped distinguish certain interview data and grouped certain codes together under an umbrella of the preset codes. For example, "leadership" and "representing fraternity on campus" were grouped under the personal growth pre-set code. Descriptive coding gave a categorical framework that separated men's perceptions of their college experiences, accounts of encountering instances on campus from BGLF affiliation, men's relationships with their peers and women, and student involvement on campus. Once the codes were created, interview data were filtered and funneled into one or multiple codes. The qualitative software, NVivo 9, was used to organize and separate the data.

Strategies for Validating Findings. It was helpful to review data that described men's narratives of their Greek affiliation on their campus. Their perceptions helped guide my writing of the findings. As I reviewed the literature and collected my data, I paid attention to how the men's examples and ideas related back to the research, and I continued to use a critical viewpoint. This study used in-depth, semi-structured interviewing to examine how the institutional context may influence the experiences black men encounter and how it affects their personal and professional development. Through a grounded analysis of interviews and participant observation, I find that membership in BGLFs produce negative outcomes for black men (Andersen, 1993; Denzin \& Lincoln, 1994; Strauss \& Corbin, 1994). 


\section{Table 1}

Descriptive Statistics of Black Greek Letter Fraternity (BGLF) Members

Race/Ethnicity

Black/African American

Haitian

Nigerian

Biracial

Age

18-20 years old

21-23 years old

$24+$ years old

Household Composition

Two-Parent Household

Nuclear

Step/Blended

Single Parent Household

Mother

Father

\section{BGLFs*}

Beta Sigma Rho Fraternity Incorporated $(\beta \Sigma \mathrm{P})$

Gamma Xi Fraternity Incorporated (МГE)

Theta Psi Pi Fraternity Incorporated $(\theta \Psi \Pi)$

Note: $\mathrm{N}=20$

*BGLF Pseudonyms

\section{Number of Respondents}

15

1

2

2

9

9

2

14

5

4

3

1

8

5

7 


\section{Findings}

Black fraternity members described how, in the long run, joining a fraternity improved their overall character and enhanced their college experience. However, they also described facing an array of challenges upon first joining a fraternity, and shed light on the factors that complicated their transition to fraternity life. Belonging to a BGLF required them to make certain unexpected compromises that may, at times, have adversely affected their academic and/or personal lives.

In the following sections, I will discuss the respondents' more positive personal transformations since joining a fraternity. I will then address several negative consequences the respondents revealed about being members of BGLFs. The negative themes that emerged from the interviews were: women's negative perceptions of BGLFs, which affected their interactions with women; the time demands that the fraternities imposed upon respondents, thus making them considerably busier than the average college student; and the loss of individualism they experienced since joining a fraternity.

\section{Personal Growth among BGLF men}

Respondents described undergoing a personal transformation after joining a fraternity, one in which the fraternity "saw the potential in them" such that it didn't change their identity but sharpened who they were as men. Mario, 23, elaborated on this by saying:

They think you changed, but you change for the better. Joining a Greek, it's not bringing you down. Joining a Greek builds you up, builds you up into a better man.

The BGLFs enhanced individual qualities of fraternity members, like Mario, by recognizing the potential in each member to become leaders on campus and within the black student community. Some members particularly valued their BGLF membership since they did not have consistently positive male role models in their lives, whereas other members came from fatherless households where they were not taught the lessons about manhood that other young boys may have taken for granted.

Most fraternity brothers said they had become more confident when interacting with their peers on campus and their newfound confidence had helped them pursue campus opportunities they would otherwise miss out on. Many respondents mentioned that their membership in BGLFs provided them with opportunities to showcase their leadership skills in student government positions or coordinate university events such as homecoming activities. The BGLFs broadened their members' experiences by allowing them to interact with different people, and to serve as the "face" not only of the fraternity but of the entire university through these prominent leadership positions.

Representing their fraternity's name on campus meant more than presenting a wholesome character on campus, but altering their individual behavior in order to positively impact the fraternity's reputation on campus. BGLF members displayed an earnest commitment to their fraternity by altering their dress, speech, and demeanor so that their fraternity would be known to transform boys into men. Prior to joining a BGLF, members may have demonstrated immature or childish behaviors, but through their membership in BGLFs, they had matured into young, professional black men.

Acknowledging their BGLF, many respondents admitted that they had to represent their fraternity's name everywhere they went. Brandon's comments summed this up nicely:

One of the things they teach us is that you carry the burden of [being a] Beta everywhere that you go. Not saying it is a burden, but that you carry the name of the fraternity on your back everywhere you go. Everything you do is representing the fraternity, and that is something I have to keep in mind at all times. - Brandon, 20 
My respondents were keenly aware that they were held to high behavioral standards, and their status as black fraternity men influenced more than their behavior on campus, but how they performed in their classes and in their interactions with their peers. Brandon continued:

I have to make sure I am on my p's and q's at all times. I make sure that I am always in class on time, make sure I am not missing a whole bunch of classes, [and] make sure I am not failing classes, making sure that when I am in front of people that I speak well. I am not stuttering and making a bad example out of the fraternity. - Brandon, 20

Although being held accountable for their actions both in and out of the classroom, and being held to high behavioral standards as a result of their BGLF membership, could constitute a burden of sorts, it meant that my respondents came to embody a type of young black man that was well dressed, well-spoken, disciplined, conscientious, and responsible. Crucially, these are qualities one does not often find in mainstream conversations about the state of young black men in America today.

As we can tell, belonging to BGLFs involves members' personally maturing from adolescents into young adults through their active participation in their fraternity. Membership in BGLFs enhances black men's confidence within themselves to improve their leadership skills, student engagement on campus, and pursue opportunities they previously believed they didn't deserve. From their personal transformation, members portray images of young black professionals, thereby representing their fraternity well on campus.

\section{The Unexpected Costs of BGLF Membership}

In addition to attributing numerous benefits to their membership in BGLFs, respondents also described certain negative consequences of belonging to BGLFs. Time consumption, negative interactions with women, and losing their individualism were three central themes that respondents described as negative consequences of belonging to a BGLF.

BGLFs Consuming Respondents' Personal Time. The primary change respondents reported about their college experiences after joining a BGLF was that they had more responsibilities throughout the day and appeared to be much busier than the average non-Greek college student. For instance, Elliot described the unexpected time consumption that characterized Greek life:

The thing about Greek life, when you get into it, you start doing way more than you think you [are] doing. For most people, it hurts you until you learn how to balance yourself. Elliot, 23

Several members mentioned the unexpected time constraints that BGLFs put on members' individual schedules. This illustrates that joining a BGLF produces more time obligations that require members to sacrifice their personal time in order to fulfill their responsibilities. The existing literature does little to explain how members of black Greek letter fraternities negotiate their time effectively in order to be successful in their academics and Greek lives. Some scholars (e.g., Nelson et al., 2006) find that members in Greek letter fraternities often prioritize fraternal responsibilities over academic responsibilities. All respondents expressed that their BGLFs were consuming much of their daily time, and many explained the need to improve their time management skills and to utilize their time more effectively with the "24-hours-in-a-day" mentality. Malik had this to say:

You have more time than you think you have. People say they're busy. Everyone is busy in their own sense, but when you start cutting out some of the little time, then you realize you could have spent that hour studying. [It's about] utilizing the time that you do have: your free time.- Malik, 21 
Respondents used tools to help them manage their time, such as daily planners, listing daily goals on whiteboards to plan their days, or utilizing their cell phone calendars.

My findings confirmed that current members of BGLFs were heavily involved in other student organizations prior to joining their respective fraternities. Other respondents had jobs on campus and were working in order to remain financially secure throughout college. Being affiliated with other student organizations was believed to increase the fraternities' popularity on campus by providing opportunities to recruit potential members. The outside obligations left respondents with little personal time, and they reported that the strain from time conflicts hurt their personal relationships and potential romantic relationships. As a result, much of the respondents' previously free time was consumed by their leadership roles.

This meant that they were often left with very little time to devote to maintaining personal relationships, such as family relationships and friendships. Majority of respondents stated that they did not call their loved ones as much as they used to before joining a BGLF, and others stated that they could not have friendships with others outside of the fraternities because they were consumed with Greek-related activities. Take Elliot, for instance:

Family-wise since I became involved in the fraternity, I feel like I don't have the time to call home. I haven't forgot about y'all, I [am] so busy. People back home, they don't understand how your day is set up. I don't have time to just talk on the phone and have random conversations. - Elliot, 23

Communication with family members became distant and sometimes nonexistent for members of BGLFs. The respondents acknowledged that they longed to sustain communication with their family and loved ones, but encountered time conflicts in keeping in touch with their family members. Like Elliot, respondents described how their family members did not understand their new collegiate lifestyles, and had to apologize for prioritizing their fraternal obligations over their obligations as devoted sons. As a result of the different lifestyles, many of the fraternity brothers experienced growing pains in their development from young boys into young men. They were no longer considered "mama's boys" who lived with their parents, but were growing into independent, self-sufficient, professional young men. This transition into young adulthood was particularly difficult for black fraternity men because they had strong ties to their families, especially their mothers. Having to fend for themselves and mature on their own could be problematic for these young men. However, having the support and guidance of their fraternity brothers aided in their transition into young adulthood.

Marcus articulated the struggle of maintaining personal relationships since being in a fraternity, saying:

Even though it is a social fraternity, you don't have much time to be social with people. It does take away the opportunity to build a lot of relationships. You don't have time to do that. - Marcus, 20

With the fraternities consuming most of the respondents' time, their academics tended to suffer. At times, BGLF members' concentration on their obligations to their fraternities certainly appeared to be at odds with the broader aim of helping to increase the academic success and retention of black men in college. As Elliot explained, students' academics could suffer upon joining the fraternity:

Usually when people become Greek, their first semester or so, their [GPA] goes down until they figure out how it works. That's where time management starts coming in. - Elliot, 23 
At least initially, members may devote more time to their fraternities than to their academics. Fortunately, respondents indicate that things improve after the first few semesters of belonging to a BGLF, once they learn to balance their academic and fraternal obligations more successfully.

After joining a fraternity, respondents wanted to or felt obligated to experience the social scene entirely. This was demonstrated with members attending social events, hosting parties, and traveling constantly for their fraternities so that people would know they were members of a specific BGLF. They referred to this expansion of their social lives as "Neo fever." Neo fever typically only lasts for one to two semesters, but it can impede a BGLF member's academic standing:

I got to experience what it can do to somebody who joins the fraternity a little bit too early. It can be very detrimental to the academics cause they get caught up in the social scene. Jamal, 20

Most of the respondents agreed that the semester after joining the fraternity was the most difficult one academically, because they were still adjusting to being thrust into Greek life. Many respondents said that after the first semester, they understood the importance of balancing their responsibilities and had developed effective time management skills, which led to an improvement in their grades and GPAs. Having to prioritize their commitments meant sacrificing certain obligations that hindered their full participation in the fraternity.

Time conflicts were reflected in respondents discussing their heavy involvement in BGLFs and other student organizations. As a result, many members had little personal time to devote to developing personal relationships and maintaining their academics. Respondents were often left to choose their fraternity over their personal time which may have caused disagreements between them and their loved ones. Having to sacrifice their personal relationships and academic standing for their BGLF membership did not discourage members' role in their BGLFs; it only required respondents to prioritize their time effectively in order to achieve a worthy experience within their fraternity.

Lack of Individualism. As conspicuous representatives of the fraternity on campus, several respondents mentioned that they were no longer individuals, but part of a bigger entity on campus. The "crossing over" into their fraternities gave them a collective identity that ultimately proved beneficial to their college experiences, but many became frustrated with the constant Greek association. Being a full-fledged member of a BGLF became a reality for respondents when they realized that the Greek association was their new identity on campus. Malik expressed how he was not just "Malik" but "Malik the Theta."

People will associate me as a Theta as far as stereotypes. People are immediately going to put Malik the Theta after everything. -Malik, 21

Respondents' increased notoriety required them to recognize the visibility they had on campus. In fact, several respondents suggested they were "celebrities" on the campus, and others acknowledged the accuracy of this label. Marcus described the instant popularity of the fraternity by saying, "When you're Greek, it's like everybody knows your name, and if you didn't meet [him or her] before, you are always invited to new places. Everybody wants to get to know you."

Their celebrity status on campus brought misconceptions about Greek life among nonGreek students, and students being heavily critical about the respondents' present Greek life. NonGreek students believed that joining a fraternity was only about partying with other Greek students, socializing with non-Greek and Greek students, and becoming sexually promiscuous with women. However, the fraternity stereotypes of "the players," "the partiers," and "the socialites" on campus motivated many BGLF men to challenge fraternity stereotypes and to prove to their peers that 
BGLF men were different - that they were men who could excel academically, display a high degree of student involvement on campus, and graduate in a timely manner. In frustration, Malik, 21, confessed, "[At the] end of the day, I would like to be just Malik who happens to be a Theta, but now I appreciate representing my fraternity. That's why I always do the best of my abilities." Elliot agreed that mostly non-Greek students judged him negatively because of his fraternity. He explained, "People judge you being a part of fraternities. They already got a stereotype about you, so they talk about you a lot. People expect us to have higher standards."

As part of adjustment to Greek life, other respondents described a newfound lack of personal privacy within their social networks. Many expressed frustrations with the public knowing more about their lives, and how easily accessible the details of their lives were through their social media accounts.

Several men described finding out that rumors about them and their fraternities were being circulated throughout the black community. Others explained that their social media accounts had greatly expanded, with dozens of new followers and friends. Some saw this as a net positive, while others, like Reggie, were less upbeat: "Everyone knows you. They can find your Instagram, your Twitter. You are so easy to be accessible to them. They know your business too. It's not really your life, just people's perception of it."

Having their personal lives accessible to the public limited respondents' ability to control who obtained their personal information. In this situation, "appearing available" negatively impacted respondents, with more women entering their social circles. Participants were selective when interacting with women, yet these women could have hidden motives that would damage respondents' social status. Nevertheless, many respondents said they could identify the women who could damage their social status. Elliot simply stated:

When you become Greek, it's a different crowd of females that come at you, that come around you. Those [are] the types of girls that want to party all the time. You learn how to spot one. - Elliot, 23

Furthermore, respondents expressed the difficulty in adjusting to Greek life from their newfound identity, being the center of attention for their peers' judgment, and having no privacy within Greek life. Since joining the fraternity, a "shift" had taken place in which their BGLF membership had altered their social, academic, and personal lives. Majority of respondents expressed difficulty in adjusting to their new college lives since "going Greek" because of their diminished individual identity into their collective fraternal identity. Even though, respondents expressed that their individualism was stripped from them since becoming members of their black Greek letter fraternities, many respondents believed that their Greek affiliation nevertheless enhanced their college experiences.

Negative Effects on Interactions with Women. Navigating the extended social scene became a main focus for the respondents when they first joined their black Greek letter fraternities. Particularly during interactions with women on campus, respondents found that their popularity attracted a large group of women. This allowed them to expand their social networks on campus. However, many of them expressed that interactions with women were oftentimes negatively affected because women perceived their fraternity based on negative stereotypes.

The imperative of "appearing single and available" caused many BLGF members to play the field and interact with numerous women. Their increased interactions with women resembled white fraternity men's interactions with women on campus. In other words, BGLF men were objectifying women similarly to white fraternity men. However, the black fraternity men faced a greater backlash from the student community for their mistreatment of women. Respondents 
complained that interactions with women were particularly negative since many of the women expected BGLF men to behave more respectfully compared to white fraternity men.

BGLF men portrayed the "single man" role in order to entice greater interactions with women. The men's interactions with women extended the popularity of fraternities, therefore positively impacting the fraternities' reputation on campus. By interacting with a greater number of women, fraternities gained the reputation of being friendly and approachable, and "having the most attractive fraternity brothers." Consequently, this reputation assisted in the recruitment of potential members and increased attendance to social events and parties, thereby producing greater revenue for the fraternity.

Even though BGLFs contribute to black men's college success and, in various ways, allow black men to display positive images that challenge the stereotypically negative images of black men that loom large in the public imagination, there are times when membership in BGLFs can perpetuate the negative assumptions that accompany young black men. The BGLF men portraying the "single man" role can perpetuate the notion that black men are "players" who are only after the sexual conquest of women. The greater number of women interacting with them allowed the BGLF men to capitalize on and successfully navigate the sexual realm of college life. In order to acquire more sexual conquests, respondents had to play the role of "appearing single and available" at all times. Elliot, 23, thought that this was a part of playing the "fraternity role":

You got to play the role. You want to be successful on campus...you got to play the role.

While you interacting with females, you build relationships. - Elliot, 23

Having to "play the role" by "appearing single and available" fosters two stereotypes about BGLF men: being the typical "frat guy" and being "the player." BGLF men are plagued by the possibility of perpetuating both stereotypes whenever they are promoting their fraternities' social events, but they are expected to do so in order to contribute to the financial advancement of their respective BGLFs.

Curiously, though, most respondents said that women rebuffed their advances whenever they discovered that they belonged to a BGLF. Women did not want to associate with specific BGLFs because of the rumors they had heard, past negative interactions with their members, or did not want to deal with the challenges of becoming involved with a BGLF man. These assumptions translated into the negative stereotypes associated with each black fraternity, therefore limiting their interactions with women. Mark suggested that the nature of the interactions could be explained by the woman's year in college:

It goes by year honestly. If they are a junior-senior, they will not talk to you. But freshmen and sophomores, it's cool to them. It attracts them. They are going to come running and throw their legs at you. - Mark, 20

Mark was of the opinion that women would have an increased interest in BGLF men during their freshmen and sophomore years, but that their interest in BGLF men would lessen during their junior and senior years. One possible reason for women's decreased attraction to BGLF men would be that they had experienced the party scene entirely and were no longer "star stuck" by BGLF men. Secondly, the women would be focused on transitioning out of college, so they would devote less time to interacting with BGLF men.

BGLF members reported that their negative interactions led to severe trust issues with women. Many of the respondents believed that they were not in a place to trust women entirely and have healthy romantic relationships with them. Several respondents attributed this problem to their involvement in Greek life: they could not trust or discern peoples' true motives in their social 
networks. The following comments describe the men's trust issues with women, and how they impacted the development of romantic relationships with women:

Once I crossed, I had a girlfriend, then the influx of women that were giving me attention was a bit much to handle, so we had to break up. And that did hurt cause I did feel like she was a good one, but I had so many other women after her that I didn't feel right to go back [to her]. - Marcus, 20

You start learning more about females, and it's hard to trust females as a fraternity member cause you see stuff, you hear stuff, and females do more weirder stuff to fraternity members than they do to regular guys. - Elliot, 23

The popularity that comes with joining a BGLF contributes to the young men's inability to trust the women they interact with. The BGLF men's trust issues affect their perspectives on dating and pursuing romantic relationships in college. Fraternity brothers may challenge the "player" stereotype by developing friendships and romantic relationships with women, in spite of the trust issues they may have with women. However, only four participants were in romantic relationships, while the rest were single and not looking to settle into romantic partnerships in college. Most respondents said it would be selfish to participate in a romantic relationship knowing that they could not fully devote the time and attention needed for the relationship to be mutually fulfilling. Malik, 21, said, "At first there is no way I could be able to manage a [romantic] relationship. I feel like I can't give that other person as much time as I would want to, without making my school or fraternity lower."

Once a black man has become a member of a black fraternity, he begins to receive increased attention from women. However, respondents suggest that women reject their romantic advances because of the portrayal of the "single man" role in fear of BGLF men being "players." Interestingly, respondents express trust issues with women and the popularity of BGLFs making it difficult to establish romantic relationships with women. Moreover, respondents said that "going Greek," meant sacrificing romantic relationships with women that were not as important to their college experience as they might be to the college experiences of non-Greek students.

All in all, I find that young black men in black Greek letter fraternities (BGLFs) benefit greatly from an improved college experience, demonstrating academic success, expanded social networks, and an enhanced social life. These benefits do come at a cost, however, and BGLF membership cannot be said to alter these young men's lives in strictly positive ways. A lack of individualism within the BGLFs, the diminished quality of certain personal relationships, particularly those with women, and the fraternities' consumption of a majority of respondents' personal time are the primary negative aspects of involvement in BGLFs. Ultimately, black fraternity brothers generally feel that the rewards that stem from their involvement in BGLFs are well worth the sacrifices that they are required to make.

\section{Discussion}

This study has examined how black Greek letter fraternities produce positive and negative outcomes, which affect their members' overall college experiences. Through in-depth interviews, black fraternity members described experiencing a personal sense of growth or maturity. At the same time, however, belonging to BGLFs required students to make certain sacrifices, such as sacrificing family or personal relationships in order to devote the majority of one's personal time to the fraternity. This, in turn, negatively impacted the quality of their personal relationships and

lessened their sense of individuality. Interviews also reveal the adjustments that men made so that they would not be negatively impacted by their Greek affiliation. 
Similar to findings by Harper (2007), Guiffria (2003), Patton et al. (2011), and McClure (2006), findings from this study support the idea that black Greek letter fraternities play an important role in the social and academic integration of their members into predominantly white institutions (PWI). As in studies by Kimbrough and Hutcheson (1998), and Pike (2003), fraternity members tended to hold leadership positions in other student organizations such as student government.

But membership in BGLFs did not always produce rewarding experiences. My findings corroborate earlier research that BGLF members' academics drastically declined after joining their fraternities, a phenomenon popularly referred to as "Neo Fever" (Ekici \& Tingir, 2019; Nelson et al., 2006; Pascarella \& Terenzini, 1991; Pike \& Askew, 1990; Wayessa, 2017). Nelson et al. (2006) suggested that students' GPAs may decline upon joining a fraternity due to the difficulty of balancing coursework with their social engagement in Greek life. According to my findings, BGLF men's GPAs do decline within the first and second semesters after joining their fraternity. However, my results also indicate that BGLF men's GPAs improve beyond the second semester of joining their fraternity.

This study's findings are consistent with Ray and Rosow's (2012) findings regarding visibility and accountability mechanisms coerce BGLF men to be educated, respectful young men on college campuses in order to represent their fraternity well. Because mostly white students surrounded them, the young black men in this study experienced high levels of accountability and visibility from their peers and university administrators.

Ray and Rosow (2010) found that BGLF men's treatment of women differed from white fraternity men's because the black men approached women using romantic language and did not directly objectify women. When black fraternity men objectify women, they exhibit traits of the typical "frat guy," which are personified by white fraternity men. However, my results found that women would reject the respondents' approaches and romantic gestures outright. Despite this, respondents do acknowledge that they have deep-seated trust issues with women which keep them from pursuing romantic relationships with women entirely. The findings from this study differ from previous literature, which generalizes women's attraction to fraternity brothers and suggests that women are infatuated with fraternity men.

The black fraternity men in this study challenged many stereotypical black images, which are perpetuated in mass media, by establishing new ways of defining their manhood through relationships with other black men. As part of that broader scholarly effort, this study begins to describe how Greek organizations influence black men's lives in college. Black Greek letter fraternities provide black men with the opportunity to present an alternative model or standard of black manhood that depicts how black men conduct themselves in professional settings on college campuses, and the ways in which black men contradict the "uneducated thug" stereotypes that are perpetuated by certain segments of the media. My interviews with these men offer clear examples of the difficulty of constructing a black male identity during young adulthood when finding oneself surrounded by academically-oriented, professional black male role models, often for the first time. This study will contribute to a change in the discourse about young black men, chronicling how black men navigate the intersecting and interacting identities of being a black man, a member of a black Greek letter fraternity, and a black college man attending a primarily white institution. These are young men whose experiences are often ignored or hidden from view in the popular discourse of the "black male crisis," yet whose stories and experiences are of vital significance. 


\section{Implications for Practice}

The grounded theoretical framework has guided a great deal of sociological research into informing data and shared narratives of individuals that may be unknown in qualitative research. This study adds to the understanding of the grounded approach, and more specifically black men's experiences. The encounters analyzed in this study were not only beneficial but hindering to their college perceptions. And they were a common experience in these men's everyday lives as they went about their experiences of being fraternity men.

One implication of the findings is that Greek letter fraternities are promoted to students as a mechanism for academic and social success in college. However, these findings illustrate that Greek letter organizations may present negative consequences for members, especially for minority students. Administrators and university student activities coordinators should orchestrate programs or workshops for students to educate them about the damaging effects of joining a Greek letter organization. University officials could partner with their campus National Panhellenic Council (NPHC) in programming targeted toward students of color. A recommendation for the university would be that the programs could be student-created and student-led.

Another implication of the findings illustrates the demand for safe spaces for conversation among black men which could be a valuable change. This could be accomplished through programs that offer mentoring services and networking relationships with same-race students that increase their student engagement and college success. Student organizations can provide spaces for minority students to feel validated and heard which can positively affect their college performance.

\section{Limitations}

There are several limitations to this study. This study only interviewed black men affiliated with Greek fraternities in the southeastern region of the U.S. Therefore, the findings are not nationally representative of the experience of black college men. Men's experiences of their Greek membership are likely to vary across regions, and my conclusions may not apply to settings outside of the southeast. Also, black men attending other types of schools, such as community colleges or elite universities, may have more encounters with peers, or less.

Additionally, the likelihood of homogeneity increased due to the way I recruited respondents (Weiss, 1994). Using a combination of convenience and snowball sampling techniques I was fortunate to gather men from a variety of backgrounds, but nevertheless, I did not recruit many men from the other two black Greek letter fraternities. I also relied on men's accounts in regard to their peers' perceptions of being Greek, and their peers' versions might vary in regard to what really happened.

Lastly, some participants chose not to answer questions during their interviews that may have revealed hazing tactics during pledging, and questions about their romantic relationships with women. A reason could be because the interviewer was a woman; however, participants were ensured confidentiality during the interviews, which allowed them to answer questions freely.

\section{Suggestions for Future Research}

Future research should continue to analyze how black Greek letter fraternities (BGLFs) influence how black men define their masculinity. Researchers might also conduct a comparative analysis of black fraternities and another group with a large representation of black college men: black male student athletes. It would be interesting to address the differences between the two groups in terms of visibility, treatment of women, behaviors on campus, etc. Finally, studies have illustrated how BGLFs contribute to black men's academic success in college. Scholars should closely examine how BGLF members actually utilize their professional networks upon graduating 
from college. The results would contribute to the long-term benefits of joining a black Greek letter organization in college.

\section{Declaration of Conflicting Interests}

The author declared no potential conflicts of interest with respect to the research, authorship, and/or publication of this article.

\section{Funding}

The author received no financial support for the research, authorship, and/or publication of this article.

\section{References}

Advancing success for black men in college. (2014) The Children's Defense Fund, National Press Club, Retrieved from http://www.childrensdefense.org/library/data/advancingsuccess_stat_profile.pdf.

Allen, Walter. (1992). The color of success: African American college student outcomes at predominately white and historically black public colleges and universities. The Harvard Educational Review, 62(1), 26-44.

Andersen, M. L. (1993). Studying across difference: Race, class, and gender in qualitative research. In J. Stanfield \& D. Rutledge (Eds.), Research in race and ethnic relations. Newbury Park, CA: Sage.

Blake, W. E., \& Darling, C. A. (1994). The dilemmas of the African American male. The Journal of Black Studies, 24(4), 402-415.

Bohr, L., Pascarella, E. T., Nora, A., \& Terenzini, P. T. (1995). Do black students learn more at historically black or predominantly white colleges? Journal of College Student Development, $36,75-85$.

Schmidt, C. K., Piontkowski, S., Raque-Bogdan, T. L., \& Ziemer, K.S. (2014). Relational health, ethnic identity, and well-being of college students of color: A strengths-based perspective. The Counseling Psychologist, 42(4), 473-496.

Denzin, N. K., \& Lincoln, Y. (1994). Handbook of qualitative research. Thousand Oaks, CA: Sage.

DeSousa, D. J., \& Kuh, G. D. (1996). Does institutional racial composition make a difference in what black students gain from college? Journal of College Student Development, 37, 257-267.

Eskici, M., \& Tinkir, N. S. (2019). Exposure to Emotional Violence: Relationship between University Students according to their Demographic Characteristics. Pedagogical Research, 4(1), em0026.

Fries-Britt, Sharon and Griffin, Kimberly. (2007). The black box: How high-achieving Blacks resist stereotypes about Black Americans. The Journal of College Student Development, 48(5), 509-524.

Ginder, S. Kelly-Reid, J., \& Mann, F. (2014). Black enrollments in higher education continue to decline. The Journal of Blacks in Higher Education. Retrieved from http://www.jbhe.com/2014/11/black-enrollments-in-higher-education-continue-to-decline

Guiffrida, D. A. (2003). African American student organizations as agents of social integration. Journal of College Student Development, 44(3), 304-319. 
Harper, S. R. (2007). The effects of sorority and fraternity membership on class participation and African American student engagement in predominantly white classroom environments. College Student Affairs Journal, 27(1), 94.

Harper, S. R. (2008). Realizing the intended outcomes of Brown: High-achieving African American male undergraduates and social capital. The Journal of American Behavioral Scientist, 51(7), 1030-1053.

Harper, S. R. (2012). Black Male Student Success in Higher Education: A Report from the National Black Male College Achievement Study. Philadelphia: University Pennsylvania, Center for the Study of Race and Equity in Education.

Hayek, J. C., Carini, R. M., O'Day, P. T., Kuh, G. D. (2002). Triumph or tragedy: Comparing student engagement levels of members of Greek-letter organizations and other students. Journal of College Student Development, 43(5), 643-63.

Hevel, M. S., Martin, G. L., Weeden, D. D., Pascarella, E. T. (2015). The effects of fraternity and sorority membership in the fourth year of college: A detrimental or value-added component of undergraduate education? Journal of College Student Development, 56(5), 456-470. doi:10.1353/csd.2015.0046

Hughey, M. (2008). Brotherhood or brothers in the 'hood'? Debunking the 'educated gang' thesis as black fraternity and sorority slander. Race Ethnicity and Education, 11(4), 443-463.

Hughey, M., \& Parks, G. (2011). Black Greek-letter organizations 2.0: New directions in the study of African American fraternities and sororities.

Hunter, A. G., \& Davis, J. E. (1992). Constructing gender: An exploration of Afro-American men's conceptualization of manhood. Gender and Society, 6(3) This Issue Is Devoted to: Race, Class, and Gender, 464-479. doi:10.1177/089124392006003007

Kimbrough, W. M., \& Hutcheson, P. (1998). The impact of membership in Black Greek-letter organizations on black students' involvement in collegiate activities and their development of leadership skills. The Journal of Negro Education, 67(2), 96-105.

Lafer, S., \& Tarman, B. (2019). Editorial 2019: (2)1, Special Issue. Journal of Culture and Values in Education, 2(1), i-v. Retrieved from http://cultureandvalues.org/index.php/JCV/article/view/34

Lopez, M. H., \& Gonzalez-Barrera, A. (2014). Women's college enrollment gains leaves men behind. Fact Tank: Pew Research Center, Retrieved from http://www.pewresearch.org/facttank/2014/03/06/womens-college-enrollment-gains-leave-men-behind

McDonald, S., Erickson, L. D., Johnson M. K., \& Elder, G. H. (2007). Informal mentoring and young adult employment. Social Science Research, 36(4), 1328-1347.

McClure, S. M. (2006a). Improvising masculinity: African American fraternity membership in the construction of a black masculinity. The Journal of African American Studies, 10(1), 57-73.

McClure, S. M. (2006b). Voluntary association membership: Black Greek men on a predominately white campus. The Journal of Higher Education, 77(6), 1036-1057.

Nelson, S., Halperin, S., Wasserman, T., Smith, C., \& Graham, P. (2006). Effects of fraternity/sorority membership and recruitment semester on GPA and retention. Oracle: The Research Journal of the Association of Fraternity Advisors, 2(1), 61-73.

Oliver, W. (1989). Black males and social problems: Prevention through Afrocentric socialization. Journal of Black Studies, 20, 15-39.

Pascarella, E. T., \& Terenzini, P. T. (1991). How college affects students: Findings and insights from twenty years research. Research in Higher Education, 32(1), 83-92. 
Patton, L. D., Bridges, B. K., \& Flowers, L. A. (2011). Effects of Greek affiliation on African American students' engagement: Differences by college racial composition. College Student Affairs Journal, 29(2), 113-123.

Pike, G. R., \& Askew, J. W. (1990). The impact of fraternity or sorority membership on academic involvement and learning outcomes. NASPA Journal, 28(1), 13-19.

Pike, G. R. (2003). Membership in a fraternity or sorority, student engagement, and educational outcomes at AAU public research universities. Journal of College Student Development, 44(3), 369-382.

Rawls, A. W., (2000). Race as an interaction order phenomenon: W.E.B Du Bois's “double conscious" thesis revisited. Sociological Theory, 18, 241-74.

Ray, R. (2012). Sophisticated practitioners: Black fraternity men's treatment of women. Journal of African American Studies, 16(4), 638-657.

Ray, R., \& Rosow, J. A. (2010). Getting off and getting intimate: How normative institutional arrangements structure black and white fraternity Men's approaches toward women. Men and Masculinities, 12(5), 523-546.

Ray, R., \& Rosow, J. A. (2012). The two different worlds of black and white fraternity men: Visibility and accountability as mechanisms of privilege. Journal of Contemporary Ethnography, 41(1), 66-94.

Roberts, G. W. (1994). Brother to brother: African American modes of relating among men. Journal of Black Studies, 24, 379-390.

Saenz, V. B., Hurtado, S., Barrera, D., Wolf, D., \& Yeung, F. (2007). First in my family: A profile of first-generation college students at four-year institutions since 1971. Higher Education Research Institute research brief. Retrieved from http://www.heri.ucla.edu/PDFs/pubs/briefs/ FirstGenResearchBrief.pdf

Smith, S. S., \& Moore, M. R. (2000). Intraracial diversity and relations among African-Americans: Closeness among Black students at a predominantly White university. American Journal of Sociology, 106(1), 1-39.

Steward, R. J., Jackson, M. R. Sr., \& Jackson, J. D. (1990). Alienation and interactional styles in a predominantly white environment: A study of successful black students. Journal of College Student Development, 31, 509-515.

Strauss, A., \& Corbin, J. (1994). Grounded theory methodology. In N. K. Denzin \& Y. S. Lincoln (Eds.), Handbook of qualitative research (pp. 273-285). Thousand Oaks, CA: Sage.

Strayhorn, T. L. (2010). When race and gender collide: Social and cultural capital's influence on the academic achievement of African American and Latino males. The Review of Higher Education, 33(3), 307-332.

Wayessa, B., S. (2017). We are not alone: conceptualizing people-things relationship in Oromo community in North America. Journal of Ethnic and Cultural Studies, 4(1), 34-43.

Weiss, R. S. (1994). Learning from strangers: The art and method of qualitative interview studies. New York: The Free Press Division of Simon and Schuster, Inc.

Wilder, D. H., \& McKeegan, H. E (1999). Greek-letter social organizations in higher education: A review of research. In J. C. Smart (Ed.), Higher Education: Handbook of Theory and Research. New York: Agathon Press.

Manuscript received March 04, 2019

Final revision received April 15, 2019

Accepted April 24, 2019 